\title{
How a Half-Million Iowa Women Suddenly Went to Work: Solving a Mystery in the State Census of 1925
}

\section{DANIEL SCOTT SMITH}

THE IOWA STATE CENSUS OF 1925 set forth and interpreted a startling transformation in the occupational profile of women in the state. No such revolution in work experience actually occurred, however. Because census officials planned to tabulate the data by machine rather than by hand, they restructured the question about occupation. As a result, the census of 1925 silently incorporated a new definition of work, which accounts for the apparent dramatic increase in the number of women in the state's work force. What in one regard was merely a mistake is, in another, an interesting episode that captures a long, contested debate as to what properly constitutes work for women. Virtually every position in the discussion left some impression on the design of the censuses, the original returns, their editing, or the published volume of results. Thus, it is important to understand how the data resulting from a seemingly objective bureaucratic process of census taking reflect both the intentions of those in charge and the degree of success in implementing the procedures.

I am indebted to Gloria McGowan for research assistance and to Margo Anderson, Deborah Fink, Nancy Folbre, and anonymous referees for the Annals of Iowa for helpful comments on earlier versions of this article.

THE ANNALS OF IOWA 55 (Fall 1996). CThe State Historical Society of Iowa, 1996. 
FOUR TERSE PARAGRAPHS and an accompanying table in the introductory section of the census volume indicated that in just a decade nearly a half-million more Iowa women over the age of fourteen had become gainfully employed.

The information obtained by enumerators as to persons engaged in gainful occupations represent a total of 1,295,814. This is an increase of 507,130 or 64.3 per cent over the report of 1915.

During the World War a larger number of men engaged in many walks of life entered the service and their places, in many instances, were filled by women. Subsequent to the war a great many of these women retained their positions and the tendency has been during recent years to show an increased number of women employees in nearly every branch of business life.

In 1915 there were 11,115 [sic] females engaged in gainful occupation. The 1925 census report shows that 586,870 women were so engaged, an increase of over 500 [sic] per cent. The 1915 report showed 678,569 males engaged in gainful occupation, and the 1925 report shows 708,944, an increase of 30,375.

The following table of comparison shows the total number of males and females engaged in gainful occupation, together with percentages, for 1915 and $1925 .^{1}$

\begin{tabular}{lcccc|cccc}
\hline \hline & \multicolumn{3}{c|}{ Total Occupations 1915 } & \multicolumn{4}{c}{ Total Occupations 1925 } \\
\cline { 2 - 8 } Industries & Male & Female & Total & Percent & Male & Female & Total & Percent \\
\hline $\begin{array}{l}\text { Agricultural } \\
\text { pursuits }\end{array}$ & 281,978 & 4,495 & 286,473 & 36.3 & 296,403 & 9,098 & 305,501 & 23.58 \\
$\begin{array}{l}\text { Professional } \\
\text { service }\end{array}$ & 21,121 & 30,307 & 51,428 & 6.5 & 27,266 & 32,207 & 59,473 & 4.58 \\
$\begin{array}{l}\text { Domestic and } \\
\text { personal }\end{array}$ & 22,657 & 32,318 & 54,975 & 7.0 & 13,289 & 502,750 & 516,039 & 39.83 \\
$\begin{array}{l}\text { Trade and } \\
\text { transportation }\end{array}$ & 171,684 & 28,392 & 200,076 & 25.4 & 159,668 & 25,320 & 184,988 & 14.27 \\
$\begin{array}{l}\text { Manufacturing } \\
\text { \& mechanical }\end{array}$ & 104,379 & 14,200 & 118,579 & 15.0 & 65,418 & 3,801 & 69,219 & 5.34 \\
$\begin{array}{l}\text { Laborers } \\
\text { unclassified }\end{array}$ & 76,750 & 403 & 77,153 & 9.8 & 146,900 & 13,694 & 160,594 & 12.40 \\
\hline \multicolumn{1}{c}{ Total } & 678,569 & 110,115 & 788,684 & 100.0 & 708,944 & 586,870 & $1,295,814$ & 100.0 \\
\hline
\end{tabular}

1. Census of lowa for 1925, 1-li. The table shows 110,115 women gainfully employed in 1915. The more than fivefold increase to 586,870 in 1925 actually represents a percentage increase of over 400 percent. 
The published census volumes, which by 1925 had exceeded one thousand pages in length, did not merely report numerical facts. An early section of the volumes in both 1915 and 1925 was labeled "Iowa Expansion in All Things." Another page in the 1925 census, headed "Why Iowa is Great," introduced the section on agricultural and miscellaneous topics. Mentioned here were not only impressive facts about Iowa's agricultural productivity relative to other states, but also its top rank in terms of literacy. Among the odd contrasts presented are that "Iowa's wool is worth more than California's strawberries," and "Iowa's hens produce more wealth each year than all of Colorado's mines." ${ }^{2}$

Whether early twentieth-century lowans were as proud of their state censuses as its compilers were of their state is uncertain. In recent years, however, demographic, social, and economic historians have begun to appreciate the unique and innovative features of the enumerations undertaken by government in Iowa. Beginning in 1895, for example, county auditors, who were in charge of supervising the process, and city and township assessors, who actually collected the data for the censuses, asked individuals about their religious affiliation. The federal government's census bureau has never had the nerve to question individuals about religion. ${ }^{3}$ Instead, the national census up to 1936 gathered statistics on religion through surveys of churches and other religious institutions. ${ }^{4}$ Only one other state-South Dakota in 1915 - collected data from individuals on this important attribute of Americans. Very likely it was following the example of neighboring Iowa in its inquiry into this subject.

In other major social and economic areas, the Iowa census was a quarter-century ahead of the federal census. The 1915 census card included a question on income from occupation in the

2. Census of Iowa for $1925,1,001$.

3. Dorothy Good, "Questions on Religion in the United States Census," Population Index 25 (1959), 3-16; Charles R. Foster, A Question on Religion (Indianapolis, 1961).

4. At both state and federal levels, there were not always sufficient funds to tabulate all of the information gathered. For example, Iowa's 1915 enumeration had individuals report on their religious denominations, but then published only the information by county that was collected from religious institutions. 
previous year and the number of years of schooling experienced. These questions do not appear in the national census until 1940. Schooling in Iowa was not thought of as merely a quantitative attribute. The schedule asked separately for years of education in common school, grammar school, high school, and college, although the first two categories were not distinguished in print until the volume published after the 1925 census.

No statute required these innovations. The census laws for both 1915 and 1925 required for each person only the "name, age, color, sex, conjugal condition, place of birth and place of birth of parents, whether alien or naturalized, number of years in the United States and in the state of Iowa, occupation, months unemployed, literacy, school attendance, and ownership of farms and homes." However, the legislature granted the Executive Council "discretion as to the construction and form and number of inquiries necessary to secure information under the topics afosesaid. ${ }^{5}$ This discretion allowed the government to expand the category of school attendance, which in the federal census applied only to school-age children, to an elaborate set of retrospective questions for adults as well. In 1925, seemingly motivated by genealogical interests, individuals provided information not mandated by the legislation: census takers asked respondents for the names of their parents, including the maiden name of their mother, their ages if alive, and the city or town and state or country in which they were married. ${ }^{6}$ Just how the question on religion was justified under the discretion granted to the executive branch is unclear.

THE 1925 IOWA STATE CENSUS, then, was a unique and innovative product. Yet its report of a revolution in women's gainful employment was flawed. That something is amiss in the reported number of gainfully employed women in Iowa in 1925 is evident from the results reported in the 1930 federal census. That census reported only 163,296 women in Iowa as gainfully

5. Supplemental Supplement to the Code of Iowa, 1915, title 2, chap. 8, sect. 171, p. 12; 1923 Laws of Iowa, 212-15.

6. Other than for identifying and tracing forebears, I can think of no other relevance for these questions. 
employed, a 16 percent increase from the 140,761 gainfully employed in 1920 . The 1930 census reported that only 7.4 percent of married Iowa women were gainfully employed. ${ }^{7}$ For both state and national census totals to be accepted as valid, we would need to postulate an explosion in women's employment, not during World War I but in the first half of the 1920s, and then a nearly equivalent implosion in the second half of that decade. Even considering the impact of the Great Depression, which began in 1929, such a scenario is wholly implausible.

Iowans who bothered to study carefully the table accompanying the discussion of women's employment had other grounds to be skeptical of the data and its interpretation. Despite the claim of increased participation "in every branch of business life," the number of women in the higher status category of professional service increased by less than 7 percent, while the number of women employed in trade and transportation as well as in manufacturing and mechanical occupations actually declined in the decade between 1915 and 1925. These decreases were nearly offset by the growth in the number of "Laborers unclassified" at the bottom of the table.

Almost the entire revolution in women's work in Iowa apparent in the contrast between the totals in the 1915 and 1925 censuses occurred in the category of domestic and personal service. Some 98.7 percent of the overall increase of 476,755 women in gainful employment in the state was in this sector. This concentration seems odd, to say the least. The 1930 national census classified half of Iowa women gainfully employed in domestic and personal service as "servants." Domestic service historically had been the most common occupation for women, but one that was rapidly being displaced by the expansion of women's activity into modern economic sectors. Nor were there changes in Iowa's economy that would lead one to believe that other major occupations in the domestic personal service sector - housekeepers and stewardesses, laundresses, waitresses, prac-

7. U.S. Bureau of the Census, Fifteenth Census of the United States, 1930: Population, vol. 4, Occupations by States (Washington, DC, 1933), table 30, p. 75. 
TABLE 1

WOMEN GAINFULLY EMPLOYED IN IOWA BY AGE, 18 AND OLDER, 1915 AND 1925

\begin{tabular}{|c|c|c|c|c|c|c|c|c|}
\hline \multirow{2}{*}{$\begin{array}{l}\text { Occupational } \\
\text { categories }\end{array}$} & \multicolumn{4}{|c|}{1915} & \multicolumn{4}{|c|}{1925} \\
\hline & $18-20$ & $21-44$ & 45 plus & Total & $18-20$ & $21-44$ & 45 plus & Total \\
\hline $\begin{array}{l}\text { Agricultural } \\
\text { pursuits }\end{array}$ & $0.2 \%$ & $0.3 \%$ & $1.2 \%$ & $0.6 \%$ & $0.9 \%$ & $0.9 \%$ & $1.5 \%$ & $1.2 \%$ \\
\hline $\begin{array}{l}\text { Professional } \\
\text { service }\end{array}$ & 7.5 & 5.4 & 1.0 & 4.1 & 6.5 & 5.3 & 1.8 & 4.1 \\
\hline $\begin{array}{l}\text { Domestic and } \\
\text { personal }\end{array}$ & 8.4 & 4.2 & 2.6 & 3.6 & 35.2 & 65.7 & 67.8 & 64.0 \\
\hline $\begin{array}{l}\text { Trade and } \\
\text { transportation }\end{array}$ & 8.6 & 4.6 & 0.6 & 3.6 & 5.1 & 3.8 & 1.9 & 3.2 \\
\hline $\begin{array}{l}\text { Manufacturing } \\
\text { and mechanical }\end{array}$ & 3.1 & 2.0 & 0.9 & 1.8 & 0.8 & 0.5 & 0.4 & 0.5 \\
\hline $\begin{array}{l}\text { Laborers } \\
\text { unclassified } \\
\end{array}$ & 0.1 & 0.1 & 0.0 & 0.0 & 3.0 & 1.7 & 1.4 & 1.7 \\
\hline Total & $27.9 \%$ & $16.8 \%$ & $6.5 \%$ & $14.2 \%$ & $51.6 \%$ & $77.9 \%$ & $74.7 \%$ & $74.6 \%$ \\
\hline $\begin{array}{l}\text { Total in age } \\
\text { group }\end{array}$ & 69,733 & 415,984 & 247,263 & 732,980 & 63,150 & 425,634 & 286,729 & 775,513 \\
\hline $\begin{array}{l}\text { Pct. of all } \\
\text { women married }\end{array}$ & $22.0 \%$ & $73.3 \%$ & $67.0 \%$ & $62.0 \%$ & $23.2 \%$ & $75.8 \%$ & $66.4 \%$ & $68.0 \%$ \\
\hline $\begin{array}{l}\text { Pct. men } \\
\text { employed }\end{array}$ & $55.9 \%$ & $94.2 \%$ & $75.1 \%$ & $84.2 \%$ & $58.5 \%$ & $91.9 \%$ & $88.5 \%$ & $88.0 \%$ \\
\hline
\end{tabular}

SOURCE: Census of Iowa for 1915; Census of Iowa for 1925.

tical nurses, barbers, hairdressers, and manicurists - had experienced such explosive expansion in employment. ${ }^{8}$

In addition to the overwhelming concentration of employment growth in the domestic and personal service category, a tabulation of women's employment by age strongly suggests that it was wives working in their own households who were counted as gainfully employed in 1925 but not in 1915. The published volume does not include a tally of gainful employment by marital status. As table 1 shows, however, the apparent change in employment was least for the youngest age group, those aged 18 through 20 . Only about a quarter of those women were currently married and, probably not coincidentally, the apparent increase in gainful employment was also about 25 percent - from 28 to 52 percent of all females in that age group. The share of gainfully employed women aged $21-44$, among

8. Ibid., table 17, p. 547. 
whom about three-fourths were married, increased by 71 percent, while for women in the oldest age group, both the fraction currently married and the increment in the share of those classified as employed was about two-thirds. In other words, the order of magnitude of the increase in employment corresponds to the proportion of women who were married in each age group.

Certainly the interpretation the authors of the census volume gave to the 1925 figures is wrong. If women continued in employment in areas they had taken over from men during the war, the increase would not have been limited to the domestic and personal service sector. What must be behind the change in the figures themselves is an unmentioned massive alteration in the definition of what it meant for a woman to be "gainfully employed."

Additional support for the suspicion of a changed definition of women's employment comes from a regression analysis of variation among the 99 counties in Iowa in 1915 and 1925 (see table 2). In the former year, more urbanized counties and those in which fewer women were married had distinctly higher rates of females over age 18 reporting occupations. In the latter year, on the other hand, those relationships had been severed. Neither of those indicators significantly influenced the rate of female employment. ${ }^{9}$ The only predictor that mattered was the rate of adult male employment, suggesting that differentials in the enumeration of occupations by counties were responsible for the variation in the result for women, a variable that was of only modest importance in 1915. At the extremes, 40.6 percent of adult females in Chickasaw County were employed in 1925, as were no less than 99.9 percent of women in Winnebago County. The overall distribution of female employment by county is an artifact of the enumeration and not a measure of the incidence of work experiences of women. ${ }^{10}$ These meaningless results for 1925 do not increase one's enthusiasm for the principle of local control, which puts administration in the hands of the governments closest to the people.

9. None of a variety of demographic, economic, or social variables had any impact.

10. In 1915 the range was between 5.8 percent (Humboldt County) and 22.1 percent (Woodbury County). 
TABLE 2

REGRESSION ANALYSES OF PERCENT OF WOMEN

AGED 18 AND OLDER EMPLOYED, IOWA COUNTIES, 1915-1925

\begin{tabular}{|c|c|c|c|c|c|c|}
\hline \multirow{2}{*}{$\begin{array}{l}\text { Independent } \\
\text { variables }\end{array}$} & \multicolumn{3}{|c|}{1915} & \multicolumn{3}{|c|}{1925} \\
\hline & $\mathrm{b}$ & $\mathbf{t}$ & Beta & b & $\mathrm{t}$ & Beta \\
\hline $\begin{array}{l}\text { Percent males } 18 \\
\text { and older employed }\end{array}$ & .15 & 2.0 & .14 & .84 & 6.4 & .56 \\
\hline Percent urban 1915 & .09 & 5.6 & .44 & .03 & 0.4 & .04 \\
\hline $\begin{array}{l}\text { Percent females } 18 \\
\text { and older married }\end{array}$ & -.37 & -6.4 & -.46 & -.23 & -0.7 & -.07 \\
\hline Constant & 20.6 & 3.5 & & 14.2 & 0.5 & \\
\hline Adjusted R-Square & \multicolumn{2}{|c|}{0.65} & & \multicolumn{2}{|c|}{0.34} & \\
\hline F-statistic & \multicolumn{2}{|c|}{61.0} & & \multicolumn{2}{|c|}{16.1} & \\
\hline
\end{tabular}

SOURCE: Census of lowa for 1915; Census of lowa for 1925.

NOTE: The $b$ stands for the regression coefficient, $t$ is a technical measure of statistical significance (absolute values above 1.96 are significant at the conventional standard of 5 in 100 times), and the Beta is the standardized regression coefficient, expressed in metric of standard deviations that may be compared to other such coefficients in the equation.

A COMPARISON of the census schedules and methods of tabulation for the 1915 and 1925 censuses reveals the reason for the huge difference in the measured female employment in the two years. In the former year, assessors filled out a three-byfive-inch card for each resident. The set of questions on the card (see fig. 1) triggered responses that conform to a modern specification of the enduringly dominant and much older definition of work as activity in the market economy. Following occupation on the card was a blank for "Months in 1914 Unemployed," and on the next line was a space for "Total earnings for 1914 from occupation." Occupations thus were activities that produced cash income and that unemployment could halt. Despite this sequence of related questions, some married women responded with "housewife," an occupational status to which these queries did not apply. ${ }^{11}$

11. For how the structure of questions influences responses to surveys, see the general discussion by Herbert H. Clark and Michael F. Schober, "Asking Questions and Influencing Answers," in Judith M. Tanur, ed., Questions about Questions: Inquiries into the Cognitive Bases of Surveys (New York, 1992), 15-48. 
FIGURE 1

1915 IOWA CENSUS INDIVIDUAL ReCORD CARD

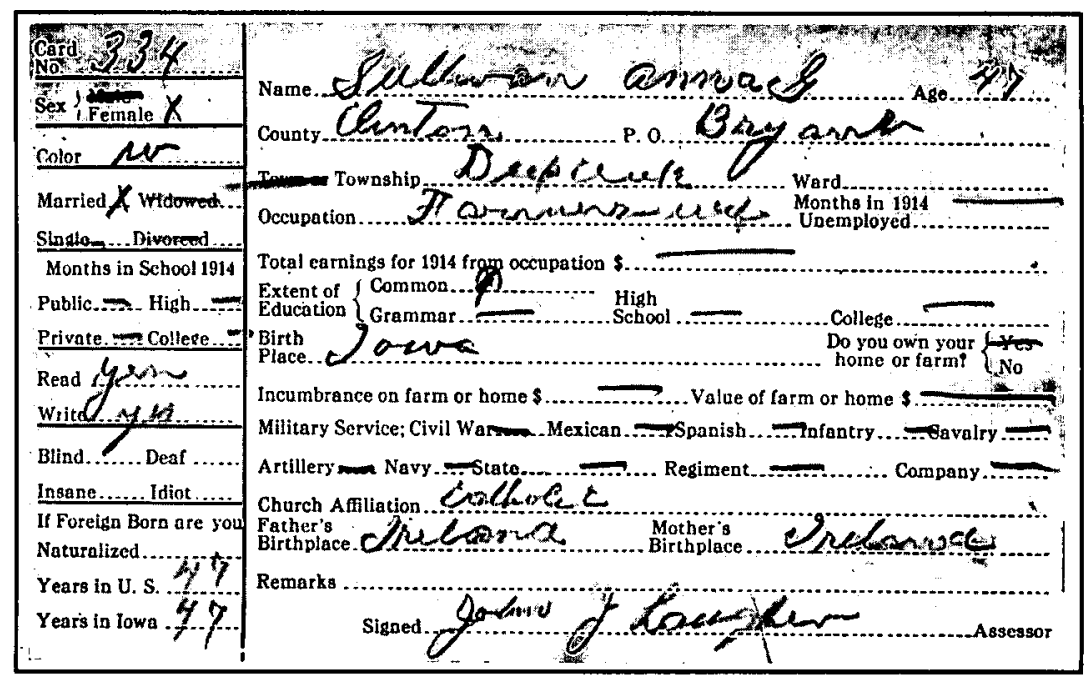

Scholars do not agree on the magnitude of historical variation in the evaluation of women's work. According to an older perspective, the crucial step in devaluing women's work occurred with urbanization and factory industrialization as production for the market became separated from household work. More recent authors contend that an earlier transition to a cashoriented market economy was responsible for the devaluation of the household-based work of women. ${ }^{12}$

In my view, there has been substantial continuity in the separate valuations of men's and women's work, although the definition of the nature of the different work roles by gender has not been constant over time. During the colonial period, white women were not eligible to be taxed as polls or tithables. Typically, white males above age 16 and blacks, females as well

12. Jeanne Boydston, Home and Work: Housework, Wages, and the Ideology of Labor in the Early Republic (New York, 1990), 1-29; Nancy Folbre, "The Unproductive Housewife: Her Evolution in Nineteenth-Century Economic Thought," Signs 16 (1991), 463-84; Nancy Folbre and Marjorie Abel, "Women's Work and Women's Households: Gender Bias in the U.S. Census," Social Research 56 (1989), 545-69. 
as males above age 16, were so taxed. Debating in the Continental Congress the basis for allocating taxes to the states, Pennsylvanian James Wilson implicitly revealed the rationale for this classification, noting that "white women are exempted from Labour generally, which Negro women are not." ${ }^{13}$ By labor, Wilson meant that most black women performed agricultural field work, while white women usually did not.

Colonial poll taxes and Wilson's comment of July 1776 illustrate what the federal census in the late nineteenth and early twentieth century defined as a "gainful occupation." The most thorough definition appeared in the instructions to enumerators of the 1930 census: "A 'gainful occupation' in census usage is an occupation by which the person who pursues it earns money or a money equivalent, or in which he assists in the production of marketable goods." Under this definition, the instructions go on to specify that a woman doing outdoor farm or garden work on a regular basis should be classified as a farm laborer. ${ }^{14}$

When the instructions to enumerators of the 1910 federal census warned that "it must never be taken for granted, without inquiry, that a woman, or child, has no occupation," measured women's employment jumped in cotton-growing counties in the South. ${ }^{15}$ No document defining gainful employment for the assessors charged with taking the Iowa census in 1915 has been located, if it ever existed in the first place, but the similarity between the results of the 1915 state census and the federal censuses for 1910 and 1920 suggests that state assessors informally took the set of occupation, unemployment, and income questions to mean "gainful employment" in the sense employed by the federal census. In 1925, occupation came to mean something else.

13. W. C. Ford et al., eds., Journals of the Continental Congress, 6:1100-1101.

14. Instructions to enumerators concerning occupations for 1870 through 1930 are conveniently compiled in U.S. Bureau of the Census, Fifteenth Census of the United States, 1930: Population, vol. 5, General Report on Occupations (Washington, DC, 1933), 23-31; the 1930 definition appears on page 29. The emphasis on farm laborer is in the original; other emphases are added.

15. Ibid., 26. 
TAKING A CENSUS is only the first step in a process. The legislature and the public want to see the results. Unlike the census schedules on large sheets used in earlier years, the $3 \times 5$ cards used by enumerators beginning in 1915 could be conveniently, if laboriously, sorted by clerks. Between April 21 and May 11, 1915, eleven women clerks, chosen for the first time by competitive examination, classified and counted the 790,000 cards with named occupations into the six groups shown in the first tables. The cards apparently had been previously sorted into three age groups for each sex and a residual category for the 1.5 million children, women, and men with no occupations. The productivity of the clerks was impressive-on average, a clerk classified an occupation every six seconds - so much so that one must wonder about their accuracy. Overall, just dealing with the occupations took the staff about eight person-months of eight-hour days of clerical time. ${ }^{16}$

There was a better way. For the 1925 enumeration, Iowa census officials designed a form that anticipated the subsequent punching and mechanical tabulation of data cards. Starting in 1890, federal census clerks no longer tallied the returns with pencil and paper. Instead, they punched holes in cards designed for an electro-mechanical counting machine invented by Herman Hollerith, who later was a founder of the predecessor of International Business Machines (IBM). By 1910, census tabulating machines could process fifteen thousand cases of a variable in a seven-hour day; about that many holes could be punched in the cards in the same span. ${ }^{17}$ Compared to one Iowa census clerk, a single tabulating machine thus promised roughly a 50 percent increase in daily productivity.

Of course, the most time-consuming aspect of dealing with occupations - and the part most prone to error - was the need for the clerk to make a judgment in classifying the occupation. Common occupations such as farmer could quickly be either

16. Memorandum of Tabulations, Executive Council Series II, 1915 Census, vol. 161, pp. 76-82, State Archives of Iowa, State Historical Society of Iowa, Des Moines.

17. Leon E. Truesdell, The Development of Punch Card Tabulation in the Bureau of the Census, 1890-1940, with Outlines of Actual Tabulation Programs (Washington, DC, 1965). 
sorted by hand or punched by machine. But other job titles were obscure or ambiguous. The Iowa solution in 1925 was to have the classification done as the census was being taken.

In order to carry out this scheme, state officials printed booklets containing lines for only 150 individuals to be enumerated in each. Ingeniously constructed, the second and third pages of information sought from each individual were not as wide as the first page that contained the name. Turning the pages thus left the name on the extended stub in full view of the enumerator (see fig. 2).

At the beginning of each booklet were two pages of instructions for the assessors. For the tenth major category-occupation - they were told:

OCCUPATION. Answer "a", "b", "c", "d", "e" and "f" as asked. Insert answer under classification which covers the occupation of the person enumerated. These questions to be answered by all persons 14 years of age or over. ${ }^{18}$

Neither the instructions in the booklet nor extant follow-up letters to county auditors from Lou F. Morgans, the census director in 1925, explained what it meant to have an occupation or, more to the point for women, what it meant not to have one. The occupation section of the schedule did not include a column that could be checked for "none," and the final sentence above indicates that a response was needed from all persons 14 and older. $^{19}$

Small details in the schedule and tabulation card suggest that the designers of the census thought it was normal for everyone over 14 to be "occupied" in some sense. Compare the treatment of religion. The schedule gives the question as "What Church are You Affiliated With," and the booklet instructions tersely instruct, "Answer as asked." Yet, in a letter to auditors, Morgans stated that entries "should be as follows: 'Protestant', 'Catholic', 'Jewish', and 'Other'," with Christian Scientists to be

18. Enumeration booklet, p. 3, Population Census of Iowa, 1 January 1925, State Archives of Iowa.

19. 1925 Census Blanks and Schedules, Executive Council, State Archives of Iowa. 


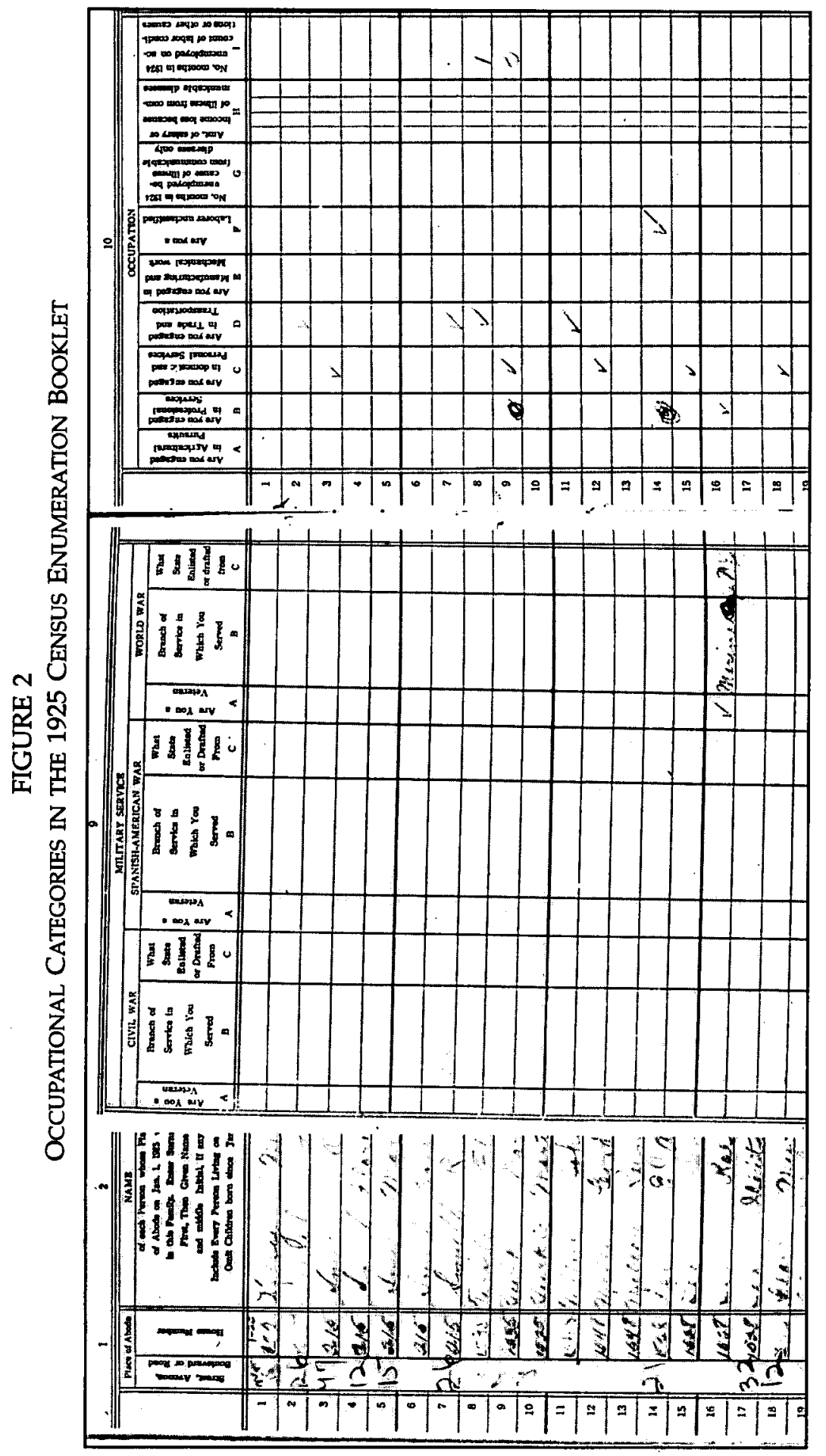


FIGURE 3

1925 CENSUS KEYPUNCH CARD

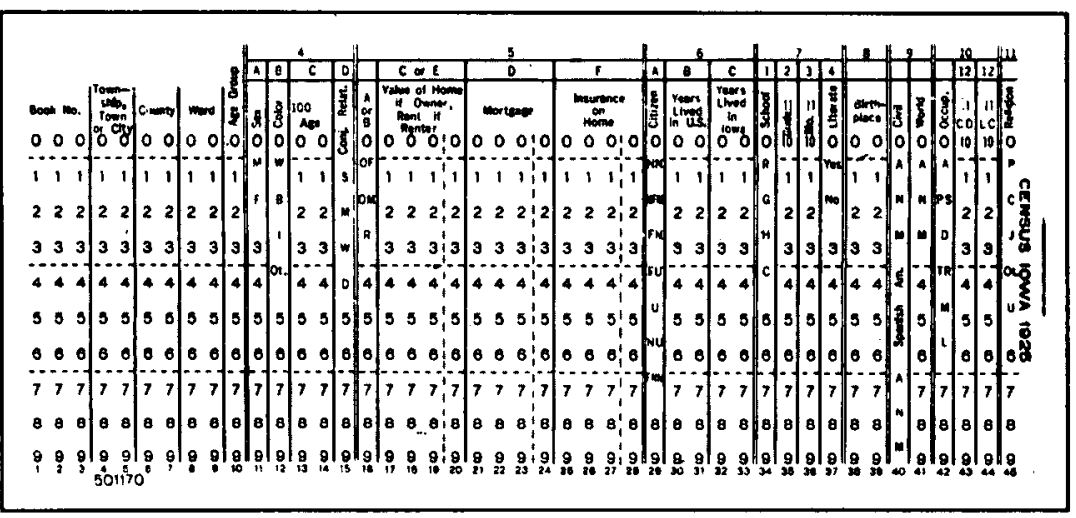

classified as Protestants. ${ }^{20}$ By direction, there were to be no explicitly unchurched, agnostic, or atheistic Iowans in 1925. But, in addition to the ambiguous "Other," the column on the punch card has a "U" location for the response "Unknown" (see fig. 3). For occupation, by contrast, the non-responses simply were not tabulated; they must be inferred from the difference between the total population in each age-sex category and the number enumerated with occupations.

The enumerators and the enumerated did not always go along with the plans promulgated by census officials in Des Moines. An impressionistic survey of enumeration booklets in a handful of counties indicates that many people supplied the name of their denomination or of a specific local church instead of the generic labels that Morgans demanded for convenience in punching the tabulation cards at the headquarters in Des Moines. "None" was also a response, albeit uncommon. On the original books, red pencil letters show the intervention of clerks. The entry Calvary Baptist, for example, was changed to " $\mathrm{P}$ " for Protestant. ${ }^{21}$

20. Lou F. Morgans to All County Auditors, 2 February 1925, ibid.

21. The editing is more difficult to read or decipher in the microfilm version of the booklets than in the originals located in the State Archives of Iowa in Des Moines. 
From the combination of the structuring of the question, the mistakes made, and the attempts by the census clerks to correct them, disparate meanings of women's work can be retrieved from the fiasco of the occupational data reported in the published census of 1925. Census takers and the enumerated generally had no problem accepting the implicit assumption that overwhelming numbers of women were employed in domestic and personal pursuits (category " $\mathrm{c}$ " in the booklets). In Bradford Township in Chickasaw County, the county with the lowest incidence of employed women in 1925, assessor C. W. Farrburg certified in some booklets that "the foregoing is a true and correct record of the information required . . . in response to diligent inquiry made by me." In these booklets, virtually all adult women are recorded as involved in domestic and personal pursuits. In booklets enumerating other parts of Bradford Township, Farrburg signed the bottom line of the affirmation in the booklet without so attesting. In these, the occupational column is checked only for male household heads, nearly all farmers. Farrburg seemingly knew what the authorities wanted but was willing to accept the conventional definition of gainful employment. In this case, no red pencil from the clerks in Des Moines intervened to enter wives or older daughters as employed in the domestic sector. ${ }^{22}$

In Bluff Creek Township in Monroe County, the site of the declining coal mining community of Buxton, on the other hand, clerks intervened extensively. ${ }^{23}$ In some instances, the original records followed the earliest understanding of women's work as being part of a productive household economy. Wives, following their husbands, were checked as being employed in agricultural pursuits. The premise here was that wives in the farm household were helpmates or assistants to their spouses in the same productive enterprise. On the other hand, red marks of the census clerks in enumeration booklets from the city of

22. Enumeration booklets for Bradford Township, Chickasaw County, 1925 Population Census of Iowa, State Archives of Iowa.

23. Dorothy Schwieder, Joseph Hraba, and Elmer Schwieder, Buxton: Work and Racial Equality in a Coal Mining Community (Ames, 1987). 
Des Moines removed wives from agricultural or other pursuits and put them instead into the domestic class.

ONE WOULD EXPECT that among the more than sixteen thousand enumeration booklets for the 1925 census, surely there would be examples in which the occupational reporting was sensitive to varying meanings of women's work among different groups of Iowans. Observers of both rural Iowa and the North generally have noted sharp ethnic variations in the reality and perception of women's roles. Herbert Quick, for example, commented that Yankees saw "the German habit of working women in the fields [as] the sure mark of the 'Old Countryman.' . . . Old Ebenezer McAllister used to say that among the Injuns the women did all the work, among the Hoosiers it was equally divided, and among the Yankees the men did it all." ${ }^{24}$ Ethnic and religious variables, however, did not statistically affect measured county variations in women's employment in 1925. That is, counties with a larger fraction of persons of German origin or Lutheran affiliation were not more likely to report higher levels of female employment. However, like C. W. Farrburg in Chickasaw County, assessors in some townships might have let the populace define what employment of women meant to them.

In cases found in Monroe, Polk, and Linn Counties, clerks used their red pencils to remove teenaged daughters from gainful employment as domestics and to put wives with no entry for occupation into the domestic and personal service category. Americans historically did not think that housewives and other adult women were idle or not working, even if they were not laboring in the sense of doing field work. Gender relations, where the household was seen as a productive enterprise, tended to be hierarchical. In the alternative view, sometimes associated

24. Herbert Quick, The Fairview Idea: The Story of the New Rural Life (Indianapolis, 1919), 6. For evidence from Hardin County, see Horace Miner, Culture and Agriculture: An Anthropological Study of a Corn Belt County (Ann Arbor, MI, 1949). For extensive documentation and analysis of these differences, I am indebted to Jon Gjerde, The Minds of the West: Ethnocultural Evolution in the Rural Middle West, 1830-1917 (Chapel Hill, NC, 1997), chap. 6. 
only with the nineteenth-century notion of separate spheres for men and women, both husbands and wives were employed in arenas thought to be complementary and equal, especially in moral value. Breadwinner and homemaker were the labels that came to be associated with this definition of separate but equal activity spheres for men and women. These terms appear for the first time in volumes published after the 1900 federal census.

The General Federation of Women's Clubs lobbied in Washington for the inclusion of a separate question for homemakers in the enumeration schedule for the 1930 federal census. ${ }^{25} \mathrm{~A}$ search of the yearbook and magazine of the Iowa Federation of Women's Clubs, however, revealed nothing to indicate that the Iowa Federation was even aware of the decisions that produced the dramatic increase in measured women's employment in the 1925 state census. Nor did the publications of the Iowa Federation mention the published volume of the state census. Its leadership, however, certainly promoted the greater recognition of homemakers within the framework of a family based more on companionship than on the ideology of separate spheres. In 1924, following the lead of the national group, the Iowa Federation created a separate Department of the American Home, agreeing, the state president noted, with "our one-time antisuffragist friends that 'women's place is in the home." To safeguard the home, however, a woman needed to be involved in civic affairs. The same issue of the magazine reprinted an article from Better Homes and Gardens by the national president of the Federation. In it, Mrs. John D. Sherman emphasized that all in the family should both work and play, noting what seemed obvious to her: "We expect father and mother to work." 26

A little more than a year later, the magazine reported the results of the national meeting of the General Federation. The rationale for the conclusion that "the most immediate need of

25. Margo A. Conk, "Improving Census Data: Lessons from the Past," in U.S. Bureau of the Census, Proceedings of the Third Annual Research Conference (Washington, DC, 1987), 17-20.

26. Iowa Federation News 5 (November-December 1924), 1, 14-16. John Demos summarizes such themes under the image of the family as an "encounter group" in Past, Present, and Personal: The Family and the Life Course in American History (New York, 1986), 35-38. 
the American home is a recognition of home-making as a vocation and the home as a business and educational center" had three parts:

1. That while the home of today has as its ultimate purpose the same ideal as did that of previous ages, the methods of homemaking, organization of the family and training of home-makers must be different. In brief, we cannot go back to the old home. We must create a new one, using the best of the material found in the old.

2. That home-making in the present age must be a partnership job between a man and a woman for which both must be trained not merely as experts or as practical machines, the one for producing money and the other for doing efficient domestic service and giving scientific care to children, but as human beings with an understanding of life through feeling and imagination as well as through the intelligence - with ideals of civic and spiritual goals as well as those of physical and economic comfort.

3. That the vocational status of the woman in this partnership job must be raised and the possible moral, social and spiritual contribution of the man must be recognized. ${ }^{27}$

This resolution called for homemaker and home to be entered in columns 26 and 27 of the federal census schedule in the same way as any other occupation and type of industry. Later, in 1928, the Federation endorsed a census treatment of homemaker apart from other kinds of occupations. This was done for the first and only time in the 1930 federal census. Only one person per household and, by subsequent definition, only a woman could be classified as a homemaker. Recording and editing of the 1925 Iowa data did not follow these rigid rules. Both middle-aged married women and coresident aging, widowed mothers were listed as employed in domestic and personal service. Nor did the presence of servants or housekeepers in a family remove the wife from employment status. Only the lower rate of employment of teenaged girls suggests the presence of a rule designating only one person as the homemaker in Iowa households in 1925.

In 1930 nearly all wives were thus officially occupied as homemakers, but this work remained conceptually distinct from

27. Iowa Federation News 6 (January-February 1926), 4. 
having a gainful occupation. Tabulations concerning homemakers appeared in the 1930 census volume dealing with families rather than the one covering occupations. The focus was on those women who were both homemakers and breadwinners. No less than 95 percent of Iowa families contained a woman designated as a homemaker, and 69 percent of women over age 15 had this role in 1930. Some 9 percent of Iowa homemakers compared to 14 percent nationally were also gainfully employed. ${ }^{28}$

THE TREATMENT OF WOMEN'S OCCUPATIONS in the 1925 Iowa census must be recognized as a disaster. The apparent surge in employment resulted from the change from an open-ended question on occupation associated with adjacent inquiries on unemployment and income in 1915 to a compulsory six-category choice adopted for ease in tabulation in 1925. Further, the discussion of the apparent revolution in women's work in the published volume was totally erroneous.

Defining women's work then or now is not straightforward. Indeed, the mechanical treatment of the question on the census form in 1925 was part of the problem. From the perspectives of national income accounting and the histories of economic growth and the laboring population, consistency of treatment over time is probably the most important criterion in devising a census definition of occupation. But such consistency can also distort changing realities. If bread is purchased rather than made at home, "employment" in the baking industry increases as does the official national product. If measuring economic growth is about ascertaining change in quantifiable aspects of human welfare rather than a mere numerical exercise, evaluating the change depends on what people do with the time formerly spent on baking. The issue is not settled even today. A section at the 1995 United Nations conference on women held in Beijing, China, grappled with the question of how governmental statistical agencies should improve the measurement of women's work. The topic remains one of normative, not just accounting significance.

28. U.S. Bureau of the Census, Fifteenth Census of the United States, 1930: Population, vol. 6, Families (Washington, DC, 1933), table 14, p. 445. 
The Iowa census treatment of occupations is certainly interesting from the perspective of the social and cultural history of women's work. Perceptions of work in the population do not correspond perfectly to those employed in official investigations. Certain activities such as keeping boarders and unpaid farm labor that should have been counted in the federal census as gainful labor were substantially underreported. ${ }^{29}$ From colonial times to the present, there has been a bias against counting women's activities, especially in the household, as labor. Yet women were not idle nor were they so regarded, even though what they were doing was not to be considered as "labor." When requested to report an occupation, as was done in the 1925 census instructions, an overwhelming majority of adult women were counted as employed in domestic and personal service. Behind this result were the troubled and inconsistent responses of the enumerated, the assessors, and the clerical editors discussed in this essay. The 1925 Iowa state census provides a window through which one can view the uncertainty and confusion surrounding women's activities and how they relate to the concept of work.

29. Claudia Goldin, Understanding the Gender Gap: An Economic History of American Women (Chicago, 1990), 219-27. 
Copyright of Annals of Iowa is the property of State of Iowa, by \& through the State Historical Society of Iowa and its content may not be copied or emailed to multiple sites or posted to a listserv without the copyright holder's express written permission. However, users may print, download, or email articles for individual use. 